\title{
UTILIZATION OF COAL GASIFICATION PRODUCER GAS FOR POWER GENERATION USING10 KW SPARK IGNITION ENGINE
}

\section{PEMANFAATAN GAS PRODUSER GASIFIKASI BATUBARA UNTUK PEMBANGKIT LISTRIK MENGGUNAKAN GENSET 10 $K W$ TIPE SPARK IGNITION}

\author{
N. NURHADI and M. ADE A. EFENDI \\ R\&D Centre for Mineral and Coal Technology \\ Jalan Jenderal Sudirman no 623 Bandung 40211, Indonesia \\ Phone: +622 6030483, Fax: +622 6003373 \\ E-mail: nurhadi@tekmira.esdm.go.id
}

\begin{abstract}
Coal gasification is the process of converting coal into gas to ease its use and more environmentally friendly. Research and Development Center for Mineral and Coal Technology (tekMIRA) has been researching, designing, and developing a small-capacity gasifier with the brand of GasMin. This study discusses GasMin design and utilization for power generation using internal combustion engine type spark ignition engine. The result of laboratory analysis shows that the calorific value of producer gas was $1,013 \mathrm{kcal} / \mathrm{Nm}^{3}$, tar content was $4.04 \mathrm{mg} / \mathrm{Nm}^{3}$, particulate content was $11.17 \mathrm{mg} / \mathrm{Nm}^{3}$ and temperature of gas was $36^{\circ} \mathrm{C}$. Based on characteristic of producer gas, it can be used for fuel in internal combustion engine. The internal combustion engine generator set (genset) used in this research was $10 \mathrm{~kW}$ spark ignition type. To be used for gas producer, some modifications were made on genset engine by replacing the function of the carburetor into mixing chamber for air and producer gas, and placed before mixing gas entering the combustion chamber. The results ofthis researchshow that the power generated was $4.8 \mathrm{~kW}$, which was about $53 \%$ of maximum power on fuel. It isin accordance with the literature whichstates that de-rating of the genset engine ranges from $40-50 \%$.
\end{abstract}

Keywords: gasifier, coal, generator set (genset), internal combustion engine, spark ignition engine.

\begin{abstract}
ABSTRAK
Gasifikasi batubara merupakan salah satu cara konversi batubara menjadi gas yang lebih mudah dimanfaatkan dan ramah lingkungan. Puslitbang tekMIRA telah melakukan rancang bangun gasifier kapasitas kecil yang dikenal dengan nama GasMin. Dalam makalah ini dibahas rancang bangun GasMin dan pemanfaatannya untuk pembangkit listrik menggunakan motor bakar (internal combustion engine) tipe spark ignition engine. Hasil dari analisis laboratorium menunjukkan nilai kalori produk gas (producer gas) $1.013 \mathrm{kkal} / \mathrm{Nm}^{3}$, kandungan ter $4,04 \mathrm{mg} / \mathrm{Nm}^{3}$, kandungan partikulat $11,17 \mathrm{mg} / \mathrm{Nm}^{3}$ dan suhu $36^{\circ} \mathrm{C}$. Data tersebut menunjukan bahwa producer gas yang dihasilkan oleh GasMin dapat digunakan untuk bahan bakar motor bakar (internal combustion engine). Motor bakar yang digunakan adalah tipe spark ignition berbahan bakar pertamax. Untuk pemanfaatan producer gas, motor bakar dilakukan modifikasi dengan mengganti karburator menjadi mixer udara - producer gas sebelum masuk ke ruang bakar. Hasil uji pemanfaatan producer gas pada motor bakar menghasilkan daya 4,8 kW, yaitu sekitar 53\% dari daya maksimum pada penggunaan bahan bakar pertamax. Hal ini sesuai dengan literatur yang menyebutkan bahwa de-rating motor bakar ini berkisar 40-50\%.
\end{abstract}

Kata kunci: gasifier, batubara, pembangkit listrik, motor bakar, spark ignition engine 


\section{INTRODUCTION}

Since 2010, Research and Development Centre for Mineral and Coal Technology (tekMIRA) has conducted research and development activities on mini gasifier design (GasMin). The first gasifier, with a capacity of 2-5 kg of coal per hour, had been made to generate producer gas $\left(\mathrm{CO}, \mathrm{H}_{2}\right.$ and $\left.\mathrm{CH}_{4}\right)$. Producer gas is a mixture of flammable gases (principally carbon monoxide and hydrogen) and nonflammable gases (mainly nitrogen and carbon dioxide) made by partial combustion of carbonaceous substances, usually coal, in an atmosphere of air and steam. The result of previous experiments conducted in 2012 revealed that the combustion still contains a lot of charcoal or coke, so that it needs modification to improve the reactivity of the carbon/coke. The development of gasifier has been successful by changing the diameter and height dimensions of the reactor in 2013 , with the aim of improving its efficiency. Gasifier development has succeeded in increasing the efficiency to be $\geq 50 \%$ (Sofaeti, 2013).

Internal combustion engine operated using producer gas was studied during 1896 using different types of engines (Fernald, 2006). Thisreport also highlights a serious limitation to the gasifier for production of good quality gas in those days. This report mentionsabout 11 types of difficulties related to gas quality and technology status which act as a barrier for promotion of producer gas engines. Most of the difficulties mentioned in this report remain unsolved even with today's status of technology (Raman and Ram, 2013). The influence of biomass gasification producer gas fuel properties on spark ignition engines performances was studied by Alexe et al. (2016) in comparisonto the natural gas (methane) and digestion biogas. To keep $\mathrm{H}_{2}$ molar quota below the detonation value of $64 \%$ for the engines using syngas, characterized by higher hydrogen fraction, the excess air ratio in the combustion process must be increased to 2.2-2.8.

Producer gas utilization, especially from biomass gasification, has been tested not only for an external combustion (gas burner) but also for an internal fuel. This paper will discuss coal gasification producer gas utilization for power generation using motor generator with type of spark ignition engine.

\section{METHODOLOGY}

\section{Coal Gasifier Setup for Experiment}

Mini Gasifier of Coal (GasMin) was used to generate producer gas (gasification). The gas that coming out from gasifier needs to be further cleaned before it is fed into an internal combustion engine (Raman et al., 2013). Producer gas will be passed on purification unit to separate tar and particulate from gas. Also, it will be passed on heat exchangers to reduce the temperature before being inserted into engine. The specification of coal gasifier can be seen in Table 1.

Table 1. The specification of coal gasifier

\begin{tabular}{|c|c|c|}
\hline No. & Parameter & Value \\
\hline \multirow[t]{4}{*}{1.} & Gasifier & \\
\hline & Diameter & $50 \mathrm{~cm}$ \\
\hline & Height & $120 \mathrm{~cm}$ \\
\hline & Water jacket & $10 \mathrm{~cm}$ \\
\hline \multirow[t]{2}{*}{2.} & Cyclone separator & \\
\hline & Diameter & 8 in \\
\hline \multirow[t]{4}{*}{3.} & Wind cooler & \\
\hline & Amount of pipe & $24 \mathrm{pc}$ \\
\hline & Diameter & 2 in \\
\hline & Length & $200 \mathrm{~cm}$ \\
\hline \multirow[t]{5}{*}{4.} & Heat exchanger & \\
\hline & Type & Shell and tube \\
\hline & Shell diameter & 8 in \\
\hline & Tube diameter & 1 in \\
\hline & Length tube & $300 \mathrm{~cm}$ \\
\hline \multirow[t]{3}{*}{5.} & Scrubber & \\
\hline & Diameter & 8 in \\
\hline & Length & $200 \mathrm{~cm}$ \\
\hline \multirow[t]{5}{*}{6.} & Fog drop & \\
\hline & Type & Packed bed \\
\hline & Diameter & 8 in \\
\hline & Length & $200 \mathrm{~cm}$ \\
\hline & Media & Ceramic \\
\hline \multirow[t]{3}{*}{7.} & Gas holder & \\
\hline & Diameter & $76 \mathrm{~cm}$ \\
\hline & Length & $120 \mathrm{~cm}$ \\
\hline \multirow[t]{6}{*}{8.} & Desulfurizer & \\
\hline & Type & Packed bed \\
\hline & Media & Activated carbon \\
\hline & Amount & 3, paralelled \\
\hline & Diameter & 8 in \\
\hline & Length & $200 \mathrm{~cm}$ \\
\hline
\end{tabular}


The design of the gasifier and purification unit can be seen in Figure 1. Cyclone separator was used to separate the particulate that carried in the gas stream. The air cooler and heat exchanger system were used to cool the gas using cooling media (air and water). During this cooling process, condensable components in the gas stream aregoing to condensed, i.e. water, tars and phenols. Condensed component was separated from the gas stream and entered the water seal at the bottom of the air conditioning and water coolers. Scrubber was worked to catch the water content, tar and phenols that still carried in the gas stream. The separation of the rest of components was done by contacting the gas and water by spraying it in counter-current mode. Fog drop was functioned to capture residual water content, tars and phenols in the form of small liquid particles (fog) and carried away with the gas flow. Residual water content, tar and phenol, were stick to the surface of the fog drop. Gas holder was used to temporarily store the gas before it passed to the desulfurizer. Desulfurizer was functioned to separate sulfur contained in gas, which consisted of $\mathrm{H}_{2} \mathrm{~S}, \mathrm{COS}$ and R-S.

GasMin performance test was conducted with capacity of $20 \mathrm{~kg} / \mathrm{h}$ coal. The proximate and ultimate analysis were conducted with ASTM D3176 and ASTM D7582 on raw coal to know its properties. It was also conducted on the ash as a byproduct of the gasification process. The gasification gas producer will be sampled and inspected for its composition using a gas analyzer. The proximate and ultimate analysis of raw coal that used can be seen in Table 2.
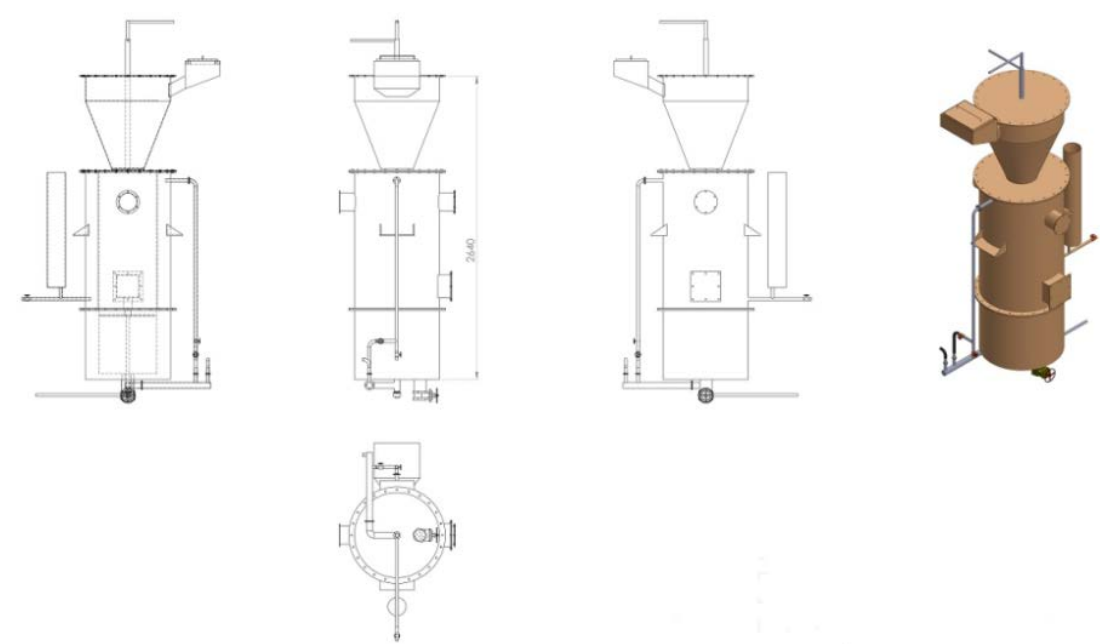

a. Design of mini gasifier

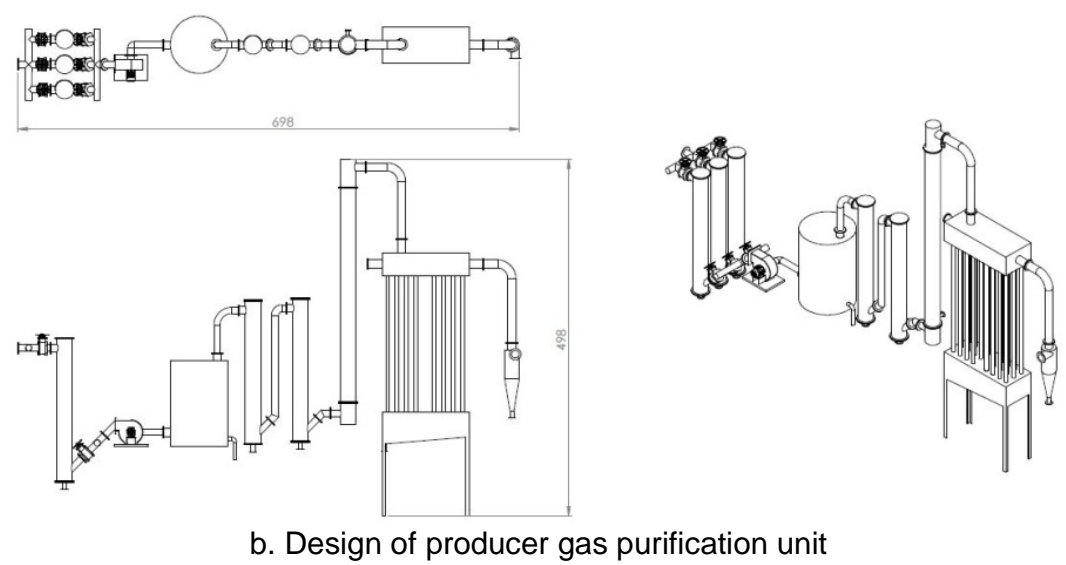

Figure 1. Integrated mini gasifier and gas purification unit 
Table 2. The proximate and ultimate analysis of raw coal (air dried basis, adb)

\begin{tabular}{clcc}
\hline No & \multicolumn{1}{c}{ Parameter } & Unit & Value \\
\hline 1 & Proximate & & \\
& a. Water content & $\%$, adb & 11.57 \\
& b. Ash content & $\%$, adb & 1.66 \\
& c. Volatile matter & $\%$, adb & 43.42 \\
& d. Fixed carbon & $\%$, adb & 43.35 \\
\hline 2 & Ultimate & & \\
& Carbon (C) & $\%$, adb & 63.73 \\
& Hydrogen $(\mathrm{H})$ & $\%$, adb & 6.17 \\
& Nitrogen $(\mathrm{N})$ & $\%$, adb & 0.96 \\
& Sulfur (S) & $\%$, adb & 0.16 \\
& Oxygen (O) & $\%$, adb & 27.32 \\
\hline 3 & HHV & $\mathrm{Kcal} / \mathrm{kg}, \mathrm{adb}$ & 5,891 \\
\hline
\end{tabular}

\section{Spark Ignition Genset Engine for Experiment}

This research used $10 \mathrm{~kW}$ genset with type of spark ignition engine. The specification of genset engine can be seen in Table 3 .

To utilize producer gas in the genset engine, the fuel feed system was modified, the carburator was replaced with mixing chamber for air and gas producer. Mixing chamber was basically a venturi pipe that connected to the engine intake manifold as can be seen in Figure 2.

Table 3. The specification of genset engine

\begin{tabular}{|c|c|c|}
\hline No & Parameter & Value \\
\hline & Engine & \\
\hline 1. & Engine type & 2 - cyl, 4 - stroke, forced air cooling \\
\hline 2. & Bore $\mathrm{x}$ stroke $(\mathrm{mm})$ & $78 \times 71$ \\
\hline 3. & Displacement $(\mathrm{mL})$ & 678 \\
\hline 4. & Compressed rate & $8.5: 1$ \\
\hline 5. & Rate power kW/(rpm) & $10 \mathrm{~kW} / 3600$ \\
\hline 6. & Max. torque N.m/(rpm) & $43.5 /(2500+-200)$ \\
\hline 7. & Ignition mode & Thyristor no-contact ignition \\
\hline \multirow[t]{2}{*}{8.} & Lubricant capacity, L & $1.5 \mathrm{~L}$ \\
\hline & Genset & \\
\hline 1. & Type & Synchronous generator \\
\hline 2. & Volt regulation & Automatic voltage regulation \\
\hline 3. & Rated voltage $(\mathrm{V})$ & 380 \\
\hline 4. & Phase & 3 phase \\
\hline 5. & Rate power (kW) & 9 \\
\hline 6. & Max power (kW) & 10 \\
\hline 7. & Rate frequency $(\mathrm{Hz})$ & 50 \\
\hline 8. & Power factor (cos phi) & 0.8 \\
\hline
\end{tabular}

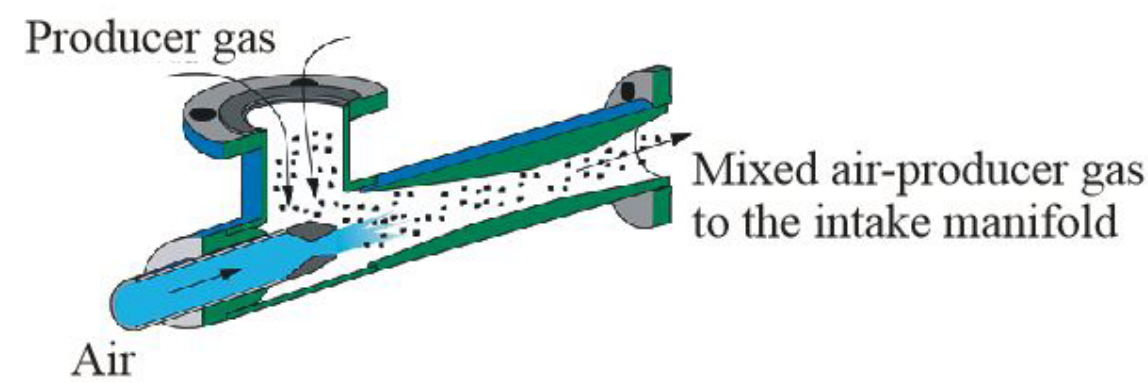

Figure 2. Mixing chamber for air-producer gas 
Low pressure of the air flow in the narrow channel at the venturi will suck up the flow of gas producer and producer gas mixed in the air flow. Comparison of air flow rate and gas producer closely arranged so that the combustion reaction was reached. The result of the calculation of producer gas stoichiometric combustion reaction showed that the mass ratio of air to gas producer was $1.25: 1$ or volume ratio was 1:1 similar with literature by Reddy and Reddy (2014).

At the time of operation, the pressure was kept constant, gas producer approached outside air pressure (atmospheric $\pm 5 \mathrm{~mm}$ $\mathrm{H}_{2} \mathrm{O}$ ), with the result that, flow of air and gas producer maintained at a volume ratio of $1: 1$. The experiment started by operating a motor fuel with a no-load power, for 30 minutes. Furthermore, the genset engine loading was done gradually $1 \mathrm{~kW} / \mathrm{h}$. Valve opening level was set manually to maintain the flow rate of mixture air-gas producer in accordance with the needs of power load of the motor fuel. If the power voltage decreases, the valve arrangement mixture flow rate of air - gas producers will more open. The addition of power load was stopped when the power supply voltage below the value of $370 \mathrm{~V}$.

\section{RESULTS AND DISCUSSION}

\section{Performance of Gasifier and Purification Unit}

Coal gasification is a reaction between coals with a mixture of air - steam into a gaseous fuel called producer gas. Producer gas is composed of gases that can be burned, such as $\mathrm{CO}, \mathrm{H}_{2}$, and $\mathrm{CH}_{4}$, and non-combustible gases like $\mathrm{CO}_{2}$ and $\mathrm{N}_{2}$. The parameter that necessary when producer gas will be used for fuel in internal combustion engines (IC engine) can be seen in Table 4 (Affendi et al., 2010; Haslerand Nussbaumer, 2000).

Table 4. Producer gas parameters for

\begin{tabular}{clcc}
\hline No. & \multicolumn{1}{c}{ Specification } & Unit & Value \\
\hline 1. & Tar content & $\mathrm{mg} / \mathrm{Nm}^{3}$ & $<100$ \\
2. & Particulate content & $\mathrm{mg} / \mathrm{Nm}^{3}$ & $<50$ \\
3. & Temperature & ${ }^{\circ} \mathrm{C}$ & $\leq 40$ \\
\hline
\end{tabular}

To fulfill the criteria of the gas that entering the motor fuel, gas producer was passed into cooling and purification unit which consists of a cyclone separator, air cooler, heat exchangers, fog drop, scrubber and desulfurizer.

GasMin performance test has been conducted for the gasifier unit with capacity of $20 \mathrm{~kg} / \mathrm{h}$. The proximate and ultimate analysis of ash, as by product of gasification, can be seen in Table 5. The result analyses presented in Table 5 are on after dry basis (adb).

Table 5. The proximate and ultimate analysis of ash (air dried basis, adb)

\begin{tabular}{|c|c|c|c|}
\hline No & Parameter & Unit & Value \\
\hline \multirow[t]{5}{*}{1} & Proximate & & \\
\hline & a. Water content & $\%, a d b$ & 4.82 \\
\hline & b. Ash content & $\%, a d b$ & 53.42 \\
\hline & c. Volatile matter & $\%, a d b$ & 7.46 \\
\hline & d. Fixed carbon & $\%, a d b$ & 34.30 \\
\hline \multirow[t]{6}{*}{2} & Ultimate & & \\
\hline & C & $\%, a d b$ & 38.63 \\
\hline & $\mathrm{H}$ & $\%, a d b$ & 1.33 \\
\hline & $\mathrm{N}$ & $\%, a d b$ & 0.54 \\
\hline & $\mathrm{S}$ & $\%, a d b$ & 0.55 \\
\hline & $\mathrm{O}$ & $\%, a d b$ & 5.53 \\
\hline 3 & $\mathrm{HHV}$ & $\mathrm{Kcal} / \mathrm{kg}, \mathrm{adb}$ & 3,011 \\
\hline
\end{tabular}

The results of the analysis show that the composition of ash has a calorific value of $3,011 \mathrm{kcal} / \mathrm{Nm}^{3}$, ash content of $53.42 \%$, and fixed carbon of $34.3 \%$. From the calculation obtained that charcoal ash-removal rate is $5.39 \%$. This results can be considered to determine the equivalence ratio (ER) of the quantity of the air supplied for gasification of coal to the quantity of air required for the complete combustion of coal (Gai and Dong, 2012; Son et al., 2011; Salam and Bhattacharya, 2006).

Properties of producer gas (gasification yield) can be seen in Table 6 . The results of the analysis show that the composition of producer gas has a calorific value of 113.88 Btu/cuft equivalents to $1,013 \mathrm{kcal} / \mathrm{Nm}^{3}$. $\mathrm{H}_{2}$ content was $0.04 \%$, it was below the typical values of around $10 \%$. 
Table 6. Properties of GasMin producer gas

\begin{tabular}{clcc}
\hline No. & \multicolumn{1}{c}{ Parameter } & Unit & Value \\
\hline 1. & Producer gas & & \\
& composition & & \\
& $\mathrm{N}_{2}$ & $\% \mathrm{~mol}$ & 58.67 \\
& $\mathrm{CO}_{2}$ & $\% \mathrm{~mol}$ & 5.09 \\
& $\mathrm{CO}$ & $\% \mathrm{~mol}$ & 34.74 \\
& $\mathrm{O}_{2}$ & $\% \mathrm{~mol}$ & 1.21 \\
& $\mathrm{H}_{2}$ & $\% \mathrm{~mol}$ & 0.04 \\
& $\mathrm{CH}_{4}$ & $\% \mathrm{~mol}$ & 0.24 \\
2. & Relative density & $\mathrm{Btu} / \mathrm{cuft}$ & 0.65 \\
3. & HHV & $\mathrm{Btu} / \mathrm{cuft}^{3}$ & 113.88 \\
4. & Tar content & $\mathrm{Mg} / \mathrm{Nm}^{3}$ & 4.04 \\
5. & Particulate content & $\mathrm{Mg} / \mathrm{Nm}^{3}$ & 11.17 \\
6. & Temperature & ${ }^{\circ} \mathrm{C}$ & 36 \\
\hline
\end{tabular}

Tar content, particulate content and temperature of the gas producer were 4.04 $\mathrm{mg} / \mathrm{Nm}^{3}, 11.17 \mathrm{mg} / \mathrm{Nm}^{3}$ and $36^{\circ} \mathrm{C}$. This result shows that the purification unit has been successful in purifying producer gas and the producer gas was qualified as fuel for genset engine. The purification process produces a mixture of water and tar that condenses. The results of the analysis showed that the water content in the mixture of phenol and tar was $98.5 \%$ with $0.06 \%$ carbon residue. The mixture of phenol and tar can be further processed to obtain water that can be circulated for purification process.

\section{Performance of Spark Ignition Genset Engine Using Producer Gas}

Thisexperiment was conducted using pertamax as a comparison fuel for genset engine. It was done for performance comparison of producer gas as a fuel for genset engine with the original fuel of pertamax. The results can be seen in Figure 3.

Figure 4 shows performance of the genset engine using pertamax as a fuel. The results accordance with the specifications, the engine generates power of $9 \mathrm{~kW}$ with voltage of 370-380 volts. While experiment using GasMin producer gas, it can generate power of $4.8 \mathrm{~kW}$ with voltage of $370-380$ volts which is about $53 \%$ of maximum power. It means there is a de-rating of the power generates by $46 \%$. This result wassimilar with the literature where de-rating of the genset engine with ignition spark type ranged from 40-50\% (Raman and Ram, 2013; Sridhar and Yarasu, 2010; Tsiakmakis et al., 2014). It is also in accordance with the results of Gobbato et al. (2015), that presented in Table 8, power derating in producer gas operation was close to $55 \%$ compared to the actual nominal fuel brake power $(254.8 \mathrm{~kW})$.

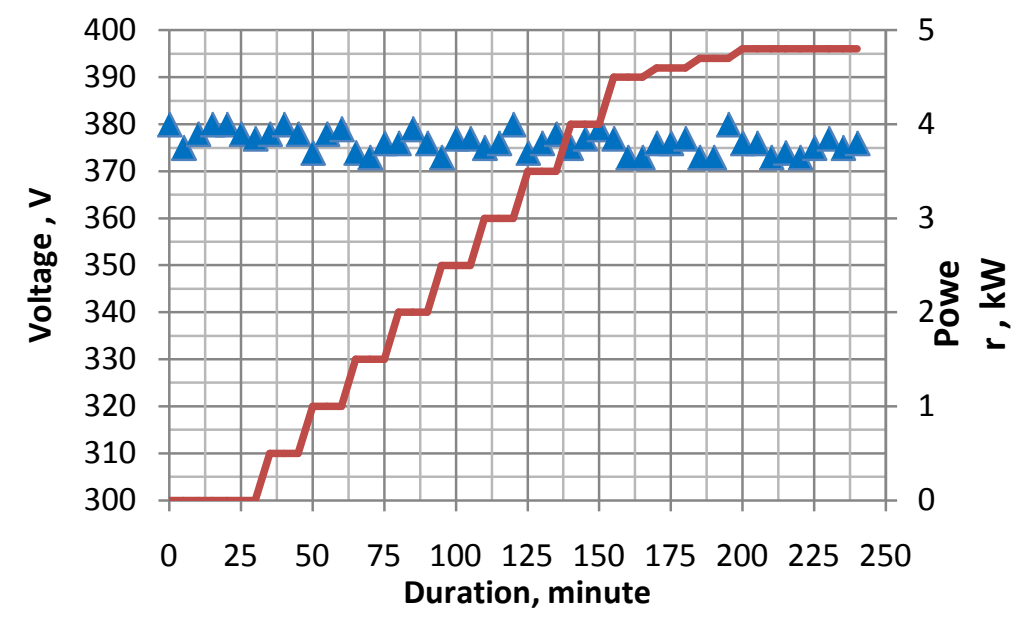

Figure 3. The result analysis of producer gas used for genset 


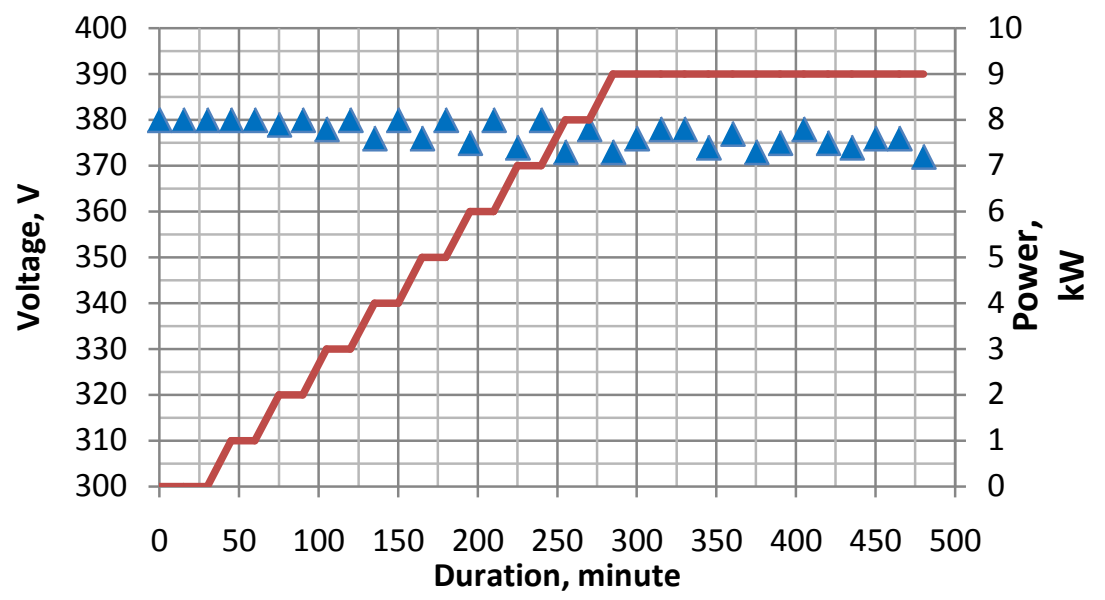

Figure 4. The result analysis of fuel (pertamax) used for genset engine

Table 7. Performance of SI engine used producer gas (Gobbato et al., 2015).

\begin{tabular}{ccccc}
\hline Test & $\lambda$ & Spark timing, $\theta\left({ }^{0}\right.$ BTDC) & Brake power, Ppc $(\mathrm{kW})$ & $\eta_{\mathrm{x}, \mathrm{PC}}$ \\
\hline \#1 (nominal) & 1.047 & 28 & 116.8 & 0.313 \\
$\# 2$ & 1.218 & 28 & 103.2 & 0.339 \\
$\# 3$ & 1.415 & 28 & 81.1 & 0.366 \\
$\# 4$ & 1.661 & 28 & 64.2 & 0.394 \\
$\# 5$ & 1.023 & 23 & 114.7 & 0.309 \\
$\# 6$ & 1.064 & 29 & 120 & 0.316 \\
\hline
\end{tabular}

Accordingto Martinez et al. (2012), low energy density of the producer gas/air mixture and the engine's low volumetric efficiency arethe main causes for the power de-rating. Due to the relatively high flame speed of the producer gas/air mixture, caused by the presence of hydrogen $\left(\mathrm{H}_{2}\right)$, the spark timing should be retarded to avoid the development of excessive cylinder pressures and achieve a higher efficiency.

\section{CONCLUSION}

Producer gas from coal gasification can be used as a fuel for spark ignition combustion engines. In this research, the temperature of the cooling gas producer was $36^{\circ} \mathrm{C}$ and has met specifications for genset engine, which is below $40^{\circ} \mathrm{C}$. The content of tar and particulate matter after purification were lower than the standards required for applied to the engine (4.04 and 11.17 $\mathrm{mg} / \mathrm{Nm}^{3}$ ). These results are good because below the thresholds, which are $100 \mathrm{mg} / \mathrm{Nm}^{3}$ and $50 \mathrm{mg} / \mathrm{Nm}^{3}$. The results of experiment show that the producer gas used in internal combustion engines generates power of 4.8 $\mathrm{kW}$ at a voltage of $370-380$ volt, or about
$53 \%$ of maximum power by using original engine fuel.

\section{ACKNOWLEDGEMENT}

The author would like to thank the R\&D Center for Mineral and Coal Technology, tekMIRA, who has funded this research and all members of the R\&D team.

\section{REFERENCES}

Affendi, M., Sugiyatno, Imam Djunaedi, Haifa Wahyu. 2010. Uji Variasi Beban Listrik dan Rasio Gas Hasil Gasifikasi Sekam Padi Pada Mesin Diesel Dual Fuel. Seminar Rekayasa Kimia Dan Proses Jurusan Teknik Kimia Fakultas Teknik Universitas Diponegoro Semarang, $\mathrm{h}$. D01-1 -D01-6.

Alexe, F., Marculescu, C. and Cenus, V. 2016. Analysis of biomass and waste gasification lean syngases combustion for power generation using spark ignition engines. Waste Management, 47, p.133140. 
Fernald, R.H. 2006. The present status of the producer gas power plant in the United States: Contributions to economic geology, part II. 2006 [Bulletin No. 316]. Washington: Government Printing Office; Available from: http://pubs.usgs. gov/bul/0316g/report.pdf.

Gai, Chao and Yuping Dong, 2012. Experimental study on non-woody biomass gasification in a downdraft gasifier. International Journal of Hydrogen Energy, 37, p. 4935-4944.

Gobbato, P., Masi, M. and Benetti, M., 2015. Performance analysis of a producer gasfuelled heavy-duty SI engine at full-load operation. Energy Procedia, 82, p.149155.

Hasler, P. and Nussbaumer, T., 2000. Sampling and analysis of particles and tars from biomass gasifier. Biomass and Bioenergy, 18, p. 61-66.

Martínez J.D., Mahkamov, K., Andrade, R.V., Lora, E.S., 2012. Syngas production in downdraft biomass gasifiers and its application using internal combustion engines. Renewable Energy, 38(1), p.19.

Raman, P. and Ram, N.K., 2013. Performance analysis of an internal combustion engine operated on producer gas, in comparison with the performance of the natural gas and diesel engines. Energy, 63 , p. 317-333.

Raman, P., Ram, N.K. and Gupta, R., 2013. A dual fired downdraft gasifier system to produce cleaner gas for power generation: design, development, and performance analysis. Energy, 54, p. 302-314.
Reddy, R. and Reddy, P. 2014. Analysis of producer gas carburetor for different airfuel ratios using CFD. International Journal of Research in Engineering and Technology, vol. 03-Special Issue: 03.

Salam, P. Abdul and S. C. Bhattacharya. 2006. A comparative study of charcoal gasification in two types of spouted bed reactors. Energy, 31, p. 228-243.

Sofaeti,Y. 2013. Pengembangan rancang bangun gasifier batubara mini untuk menunjang ketersediaan energi di UKM dan pengganti BBM pada mesin generator listrik 1 kW. Laporan Teknik, Puslitbang Teknologi Mineral dan Batubara.

Son, Young-il, Sang Jun Yoon, Yong Ku Kim, and Jae-goo Lee. 2011. Gasification and power generation characteristics of woody biomass utilizing a downdraft gasifier. Biomass and Bioenergy 35(10), p. $4215-4220$.

Sridhar, G. and Yarasu, R.B., 2010. Facts about producer gas engine, Paths to sustainable energy, $\mathrm{Dr}$ Artie $\mathrm{Ng}$ (Ed.), ISBN: 978-953-307-401-6, InTech, Available from: http://www.intechopen.com/books/pathst o-sustainable-energy/facts-aboutproducer-gas-engine.

Tsiakmakis, S., Mertzis, D., Dimaratos, A., Toumasatos, Z., and Samaras, Z., 2014. Experimental study of combustion in a spark ignition engine operating with producer gas from various biomass feedstocks. Fuel, 122, p.126-139. 